\title{
Evaluation of Photovoltaic System Performance: A Case Study in East Azerbaijan, Iran
}

\author{
M. M. Mirzaei Darian ${ }^{1 *}$, A. M. Ghorreshi², M. J. Hajatzadeh ${ }^{3}$ \\ ${ }^{1}$ Faculty of Mechanical and Energy Engineering, Shahid Beheshti University, Tehran, Iran \\ ${ }^{2}$ Faculty of Industrial engineering, Raja University, Ghazvin, Iran \\ ${ }^{3}$ Faculty of Industrial engineering, Karaj University, Alborz, Iran
}

\section{$P A P E R \quad I N F O$}

Paper history:

Received 07 February 2020

Accepted in revised form 23 February 2020

\section{Keywords:}

Economic Parameter

Performance

Photovoltaic System

Renewable Energy

\author{
$A B S T R$ A $C T$
}

Solar energy is a feasible and efficient way to reduce environmental pollution which, in turn, can decrease the production of greenhouse gases. Iran with over 300 sunny days has a high potential for producing energy, including electricity through photovoltaic (PV) systems. Regarding this fact that Iran has the enormous resources of fossil fuels such as oil and gas, the government tends to expand its energy production by renewable systems, including photovoltaics. This paper is to evaluate the efficiency of photovoltaic system in one of the major provinces of Iran. In this study, a $4.8 \mathrm{~kW}$ photovoltaic power station in East Azerbaijan province was investigated. First, a simulation-analysis is carried out. Then the verification of the study is done using extracted experimental data. According to the results, the photovoltaic power plant generates $8334 \mathrm{kWh}$ annually. Finally, the station is economically investigated. This economic analysis is carried out in accordance with the existing tariffs and policies in Iran.

\section{INTRODUCTION}

Environmental pollution and exhaustibility of fossil fuel have led various countries to move towards renewable and clean energy [1, 2]. Fossil fuels are yet the major resources for producing energy [3]. But using renewable energy is increasing in recent years so that the predictions show that by $2035,16 \%$ of the world's electricity will be produced by renewable energy [4]. Renewable energies are available in many areas of the world and energy can be produced from them, even in remote areas [5].

Among renewable energies, the sun is an endless source of energy that can easily be converted into other types of energy such as thermal, electrical and chemical [6]. Photovoltaic systems are mechanisms that can be used to produce electrical energy using sunlight [7]. The use of solar energy to produce energy is an increasing trends $[8,9]$. Electricity generation by photovoltaic systems is highly dependent on the environmental and geographical conditions of the site. Solar radiation intensity, temperature, humidity, dust as well as the wind are among environmental factors [10, $11]$.

Temperature is one of the important environmental factors which influence the efficiency of photovoltaic systems [12]. Typically, the system efficiency decreases by $0.45 \%$ per $1{ }^{\circ} \mathrm{C}$ increase in temperature [13]. One of the solutions is use of photovoltaic thermal system. These systems are such that they reduce the heat at the surface of the panels and extract the heat obtained [14-18]. Another important environmental factor is the effect of dust. Increasing the amount of dust in the air and on the surface of the panels reduces the amount of sunlight that reaches the solar cells. This can, in turn, reduce efficiency $[19,20]$.

Solar energy is one of the most suitable renewable energies for Iran as a sunny country with an average of 2800 hours of sunshine annually [21]. In addition, the production of energy by renewable and clean systems can solve the problem of air pollution in the country to a remarkable extent. This has led policymakers in Iran to plan to produce 5,000 MW of photovoltaic electricity by 2021 [22].

East Azerbaijan province, located in northwestern Iran, is one of the most suitable locations for the installation of photovoltaic systems. It is true that hours of sunshine in this province are lower than many central and southern provinces in Iran, but the low average temperature in this province has resolved this problem and can increase the efficiency of photovoltaic systems.

The economic assessment of photovoltaic electricity generation depends on the supportive policies and tariffs available in each country. In Iran, the government has been 
trying to support renewable electricity generation by purchasing guaranteed electricity for 20 years.

In this work, a $4.8 \mathrm{~kW}$ photovoltaic system in one of the villages of East Azerbaijan province was investigated. The results are based on the performance of the system. First, the amount of electricity generated by the system compared with the calculated data using simulation. Then the simulation is validated by conducting the experiment for one year (2019 $\mathrm{AD})$. Finally, an economic evaluation of the system was performed. This study is conducted according to the existing tariffs and regulations in Iran and the results were obtained.

\section{MATERIALS AND METHODS}

In this section, the materials available for performing the tests and the methods are discussed. The software and the simulation used for the study are mentioned. Finally, the economic analyses investigated in this study are discussed.

\section{System description}

In this study, a $4.8 \mathrm{~kW}$ system was investigated. The system is installed on the roof of a residential house in one of the cities of East Azerbaijan province called Darian with latitude 38.2172 and longitude 45.6305. The system comprises 15 photovoltaic panels of 320 Watts, which feed electricity into a $5 \mathrm{~kW}$ inverter and then into the global grid. The angle of the installation of the panels is 30 degrees relative to the horizon (Figure 1). The data of this system are recorded and evaluated by the data logger on the inverter. These data record and store the output of the panels in every 5 minutes.

\section{System modelling}

The simulation was performed by RET Screen Expert software. RET Screen is an energy engineering software for the estimation of clean projects. This tool is used by developers to make project feasibility cheaper and more precise before the implementation section. The outputs and information of the RET Screen are in excel format [23]. A system similar to the system is simulated in this software. A system with 15 photovoltaic panels of 320 watts and a $5 \mathrm{~kW}$ inverter. Panels with a horizontal angle of 30 degrees are also considered. Also, the inverter efficiency is $97 \%$ and other system losses are assumed to be $2 \%$.

\section{Economic evaluation}

In this section, economic fundamentals are discussed. Economic concepts are considered in this study to investigate the photovoltaic system in the area. One of the most important economic theories in electricity generation is the Levelized Cost of Energy (LCOE) which is a measure of the average net

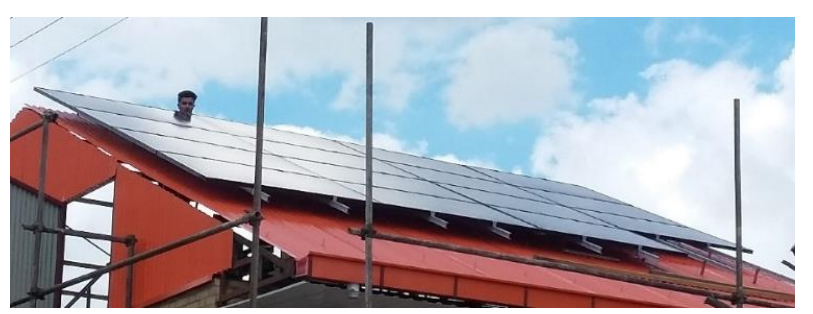

Figure 1. Photovoltaic system in Darian present cost of electricity generation for a generating plant over its lifetime [24]. This parameter allows us to compare different methods of generating electricity economically. Payback period (PP) is another important economic parameter which refers to the amount of time it takes to recover the cost of an investment $[25,26]$. Internal rate of return (IRR) is a significant parameter for appraise the amount of investment attractiveness. This is the interest rate at which the Net present value (NPV) of positive and negative cash flows for the systems are equal to zero [25-27].

\section{RESULT AND DISCUSSION}

\section{Performance analysis}

In this section, the given system is examined in terms of performance. First, this study is conducted by simulation. The results of the simulation will then be validated by conducting the experiment.

Simulation In this simulation, the energy generated by the photovoltaic system in different months is simulated. Figure 2 shows the energy generated in different months. As shown in Figure 1, the highest and lowest energy outputs are in July and December, respectively. According to the results, the energy produced through one year is $4.8 \mathrm{~kW}$ photovoltaic system in the desired geographical area is $8373 \mathrm{~kW}$. If so, the average energy produced would be $22.93 \mathrm{kWh} /$ day. The capacity factor for this power plant is $19.91 \%$.

Experimental analysis In this study, data on the photovoltaic system during 2019 were extracted and analyzed. The energy produced by $4.8 \mathrm{~kW}$ photovoltaic system is shown in Figure 3. According to the data obtained, the highest and lowest level of producing energy is in summer and winter. The months of July and December also represent the months in which the highest and lowest amounts of energy are produced. The total annual energy generated by the system is $8334 \mathrm{kWh}$. According to these interpretations, the average energy produced is $22.83 \mathrm{kWh}$ per day. According to the results, the capacity factor for this plant is $19.82 \%$.

Figure 4 shows the energy production in 365 days of 2019. To illustrate the overall behavior of the graph appropriately, a 4th-degree graph is fitted (Equation 1). As illustrated in this figure, production increased from the beginning of the year to July, reaching its peak in this month. Thereafter, production declined and as a result, production declined in December.

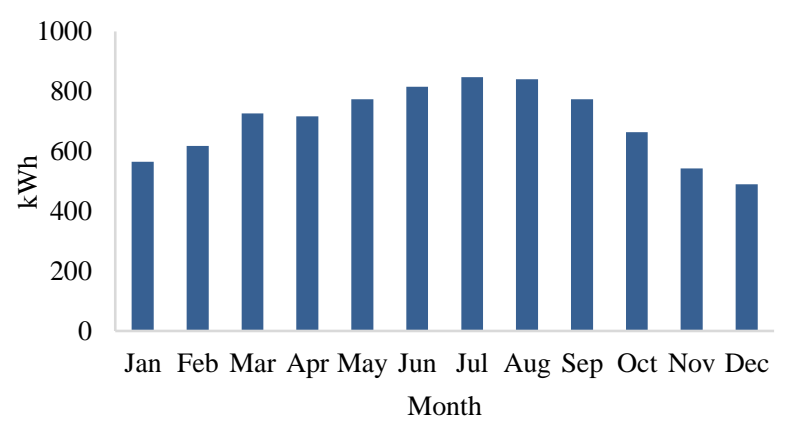

Figure 2. Calculation of energy generated by photovoltaic power plant by simulation 


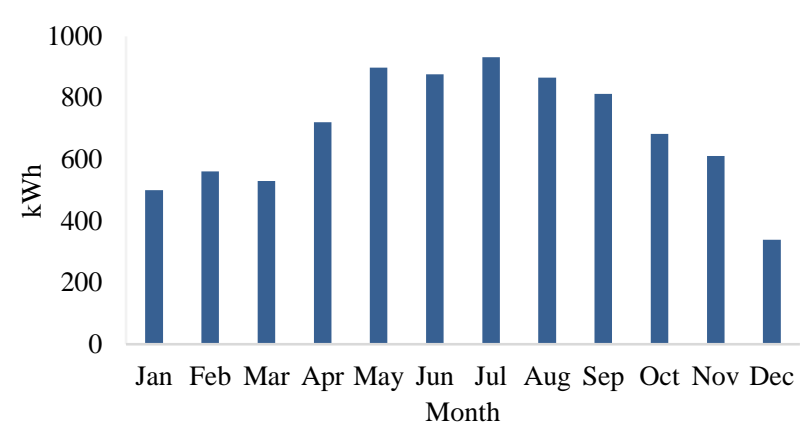

Figure 3. Calculation of energy generated by photovoltaic power plant by conducting experiments

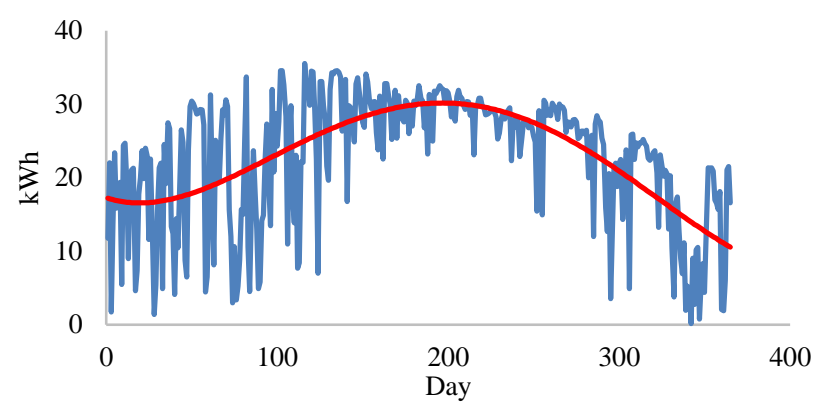

Figure 4. Energy production in 365 days of 2019

$y=1 E-08 x^{4}-1 E-05 x^{3}+0.0022 x^{2}-$

$0.076 x+17.27$

Among the different days of the year, most energies were produced on 24/4/2019. On this day the generated energy was $35.54 \mathrm{kV}$ per hour (Figure 5). This maximum production occurred on one day of spring. On this day, the sun shined less than one summer day, but the air temperature on that day was lower than the temperature on a summer day.

\section{Economic analysis}

In this section, RET Screen software is used for economic investigation of the system. These calculations are based on the weather and geographical location of the site. In this study, the initial cost of $\$ 1100$ per kilowatt is considered. In this way, the price of a power plant is equivalent to US\$5280. The maintenance and repair price is $\$ 3$ per year [24]. The exchange rate of Dollar to Rials are assumed as 1:117296. Also, the inflation rate, discount rate, and the Electricity Export escalation rate are assumed to be $20 \%, 18 \%$, and $10 \%$, respectively. The electricity produced at the power plant is

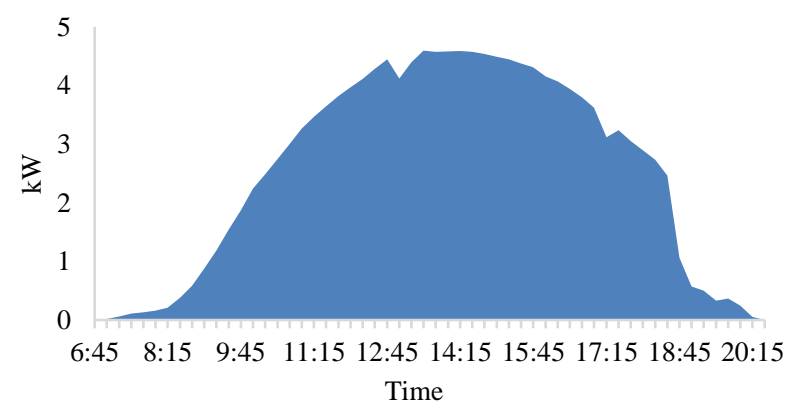

Figure 5. Most energy produced in one day in 2019 sold directly to the government and goes to the national grid. It will be sold for 20 years at 10400 Iranian Rials (US \$ 0.89) per kWh.

Figure 6 shows the Cumulative cash flows for this power plant. According to the graphs and economic calculations are carried out in this study, the PP for this plant is 5.3 years.

Figure 7 shows the power plant revenue over 20 years. IRR has been achieved $23.7 \%$. Also, one of the most important economic parameters for investigation of technology is LCOE. LCOE for the system in this paper is equal to 13.5 cents (US\$)/kWh.

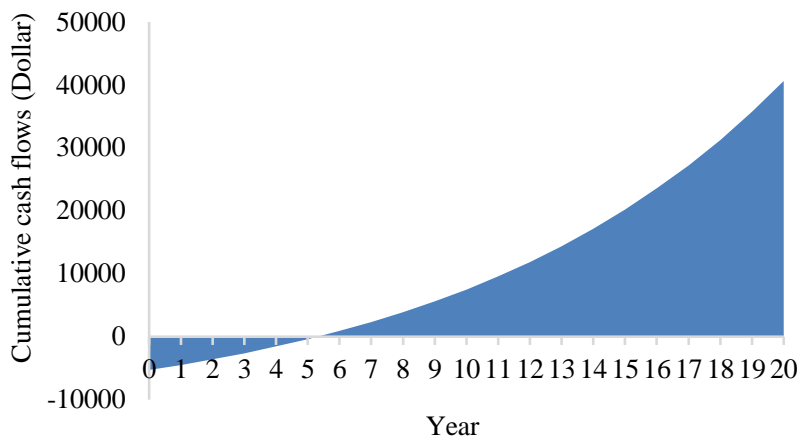

Figure 6. Cumulative cash flows for photovoltaic system

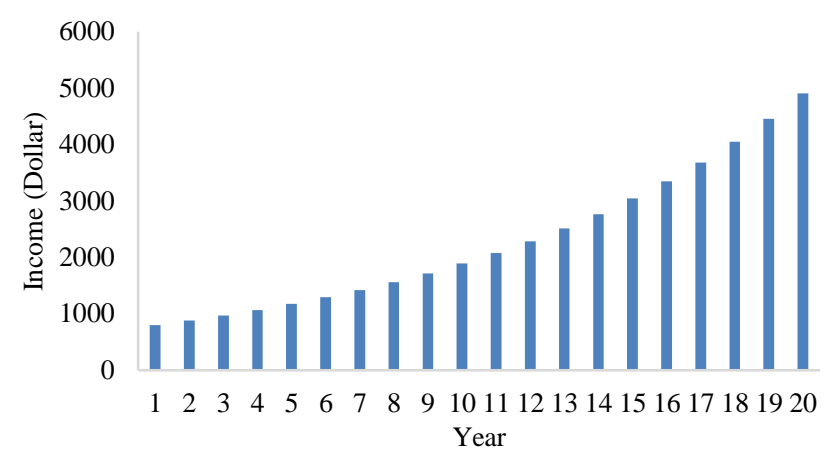

Figure 7. Incomes from photovoltaic systems

\section{CONCLUSION}

In this study, a photovoltaic system was investigated in a village of East Azerbaijan province. This study was first performed by simulation and then the results were validated by testing prototype. According to the results of the simulation, the system produces $8373 \mathrm{kWh}$ of energy annually. This number is obtained by performing an 8334 experiment, which is very close to the number obtained from the simulation. The difference between the simulated and experimental data is less than $1 \%$

In the economic sector, the IRR rate is $23.7 \%$, which is higher than the rate of bank interest in Iran and can be attractive to investors. Also, payback period has been achieved 5.3 year. The cost per kilowatt-hour of electricity generated by the plant is estimated at 13.5 cents US $\$ / \mathrm{kWh}$. This is higher than the electricity generated by fossil fuel power plants, which is one of the weaknesses of photovoltaic systems. But the strengths of these plants are water 
conservation, environmental pollution reduction and availably of the plant for consumers.

\section{REFERENCES}

1. 1. Bahrami, M., Gavagsaz-Ghoachani, R., Zandi, M., Phattanasak, M., Maranzanaa, G., Nahid-Mobarakeh, B., Pierfederici, S. and MeibodyTabar, F., 2019. Hybrid maximum power point tracking algorithm with improved dynamic performance. Renewable Energy, 130, pp.982-991.

2. Akrami, E., Khazaee, I. and Gholami, A., 2018. Comprehensive analysis of a multi-generation energy system by using an energy-exergy methodology for hot water, cooling, power and hydrogen production. Applied Thermal Engineering, 129, pp.995-1001.

3. Rouholamini, M. and Mohammadian, M., 2016. Grid-price-dependent energy management of a building supplied by a multisource system integrated with hydrogen. International Journal of EngineeringTransactions A: Basics, 29(1), pp.40-49.

4. Zandi, M., Bahrami, M., Eslami, S., Gavagsaz-Ghoachani, R., Payman, A., Phattanasak, M., Nahid-Mobarakeh, B. and Pierfederici, S., 2017. Evaluation and comparison of economic policies to increase distributed generation capacity in the Iranian household consumption sector using photovoltaic systems and RETScreen software. Renewable energy, 107, pp.215-222.

5. Biswas, A.R. and Biswas, A., 2017. Techno-economic optimization of a stand-alone photovoltaic-battery renewable energy system for low load factor situation-a comparison between optimization algorithms. International Journal of Engineering-Transactions A: Basics, 30(10), pp.1555-1564.

6. Choudhary, P. and Srivastava, R.K., 2019. Sustainability perspectives-a review for solar photovoltaic trends and growth opportunities. Journal of Cleaner Production. 227, pp.589-612.

7. Sahin, A.Z., Uddin, M.A., Yilbas, B.S. and Al-Sharafi, A., 2020. Performance enhancement of solar energy systems using nanofluids: An updated review. Renewable Energy, 145, pp.1126-1148.

8. Jamila, E. and Abdelmjidb, S., 2014. Physical Modeling of a Hybrid Wind Turbine-solar Panel System Using Simscape. International Journal of Engineering-Transactions B: Applications, 27(11), pp. 1767-1776

9. Al-Khazzar, A., 2018. A Theoretical Detailed Analysis for a Proposed $5 \mathrm{~kW}$ PV Grid-Connected System Installed in Iraq Using PVsyst Tool. Iranian (Iranica) Journal of Energy \& Environment, 9(2), pp.105-113

10. Santhakumari, M. and Sagar, N., 2019. A review of the environmental factors degrading the performance of silicon wafer-based photovoltaic modules: Failure detection methods and essential mitigation techniques. Renewable and Sustainable Energy Reviews, 110, pp.83-100.

11. Sidiki, A., Li, W. and Alhousseini, M., 2018. Experimental Evaluation of the Effect of Inclination and Dust Deposition on Production Capacity of Photovoltaic Installations in West African Nations: Case Studyin Mali Drame. Iranian (Iranica) Journal of Energy \& Environment, 9(2), pp.91-99.

12. Maftah, A. and Maaroufi, M., 2019. Experimental evaluation of temperature effect of two different PV Systems Performances under arid climate. Energy Procedia, 157, pp.701-708.
13. Hosseini Rad, A., Ghadamian, H., Haghgou, H.R. and Sarhadi, F., 2019. Energy and Exergy Evaluation of Multi-channel Photovoltaic/Thermal Hybrid System: Simulation and Experiment. International Journal of Engineering-Transactions B: Applications, 32(11), pp.1665-1680.

14. Vaishak, S. and Bhale, P.V., 2019. Photovoltaic/thermal-solar assisted heat pump system: Current status and future prospects. Solar Energy, 189, pp.268-284.

15. Chaysaz, A., Seyedi, S.R.M. and Motevali, A., 2019. Effects of different greenhouse coverings on energy parameters of a photovoltaic-thermal solar system. Solar Energy, 194, pp.519-529.

16. Rahmatmand, A., Harrison, S.J. and Oosthuizen, P.H., 2019. Evaluation of removing snow and ice from photovoltaic-thermal (PV/T) panels by circulating hot water. Solar Energy, 179, pp.226-235.

17. Preet, S., Bhushan, B. and Mahajan, T., 2017. Experimental investigation of water based photovoltaic/thermal $(\mathrm{PV} / \mathrm{T})$ system with and without phase change material (PCM). Solar Energy, 155, pp.11041120.

18. Sahota, L. and Tiwari, G.N., 2017. Review on series connected photovoltaic thermal (PVT) systems: analytical and experimental studies. Solar Energy, 150, pp.96-127.

19. Gholami, A., Alemrajabi, A.A. and Saboonchi, A., 2017. Experimental study of self-cleaning property of titanium dioxide and nanospray coatings in solar applications. Solar Energy, 157, pp.559-565.

20. Gholami, A., Khazaee, I., Eslami, S., Zandi, M. and Akrami, E., 2018. Experimental investigation of dust deposition effects on photo-voltaic output performance. Solar Energy, 159, pp.346-352.

21. Mirzaei, M. and Mohiabadi, M.Z., 2018. Comparative analysis of energy yield of different tracking modes of PV systems in semiarid climate conditions: The case of Iran. Renewable Energy, 119, pp.400-409.

22. Abdollahi, M. and Jafar Karimi, A., 2015. Areas of Priority for Policy Planning in the Sixth Development Plan of the Country in the Field of Rural Management in Iran. In Proceedings of the National Conference on Sustainable Rural Development Perspective in the Sixth Development Plan of the country, Academic Society of Geography and Rural Planning of Iran, pp. 511-496.

23. Said, Z. and Mehmood, A., 2017. Standalone photovoltaic system assessment for major cities of United Arab Emirates based on simulated results. Journal of Cleaner Production, 142, pp.2722-2729.

24. Talavera, D.L., Muñoz-Cerón, E., Ferrer-Rodríguez, J.P. and PérezHigueras, P.J., 2019. Assessment of cost-competitiveness and profitability of fixed and tracking photovoltaic systems: The case of five specific sites. Renewable Energy, 134, pp.902-913.

25. Pranadi, A.D., Haramaini, Q., Setiawan, A., Setiawan, E.A. and Ali, C., 2019. Sensitivity Analysis of Financial Parameters in Varying PV Penetrations in the Optimum Location of a Feeder. Energy Procedia, 156, pp.95-99.

26. Haramaini, Q., Setiawan, A., Damar, A., Ali, C. and Adhi, E., 2019. Economic Analysis of PV Distributed Generation Investment Based on Optimum Capacity for Power Losses Reducing. Energy Procedia, 156, pp.122-127.

27. Hammad, B., Al-Sardeah, A., Al-Abed, M., Nijmeh, S. and AlGhandoor, A., 2017. Performance and economic comparison of fixed and tracking photovoltaic systems in Jordan. Renewable and Sustainable Energy Reviews, 80, pp.827-839.

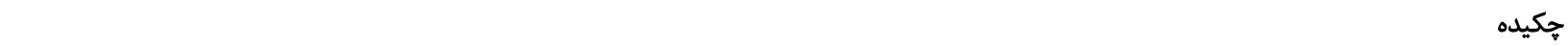

$$
\begin{aligned}
& \text { انرزى خورشيدى يكى راهحل كار آمد و امكان يذير براى كاهش آلودكى زيستمحيطى است كه توليد تازهاى كلخانهاى را كاهش مي دهد. كشور ايران با دارا بودن }
\end{aligned}
$$

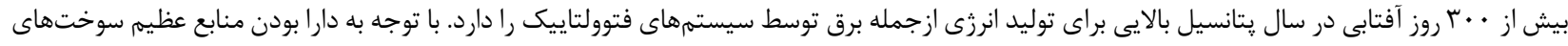

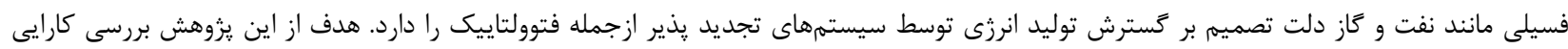

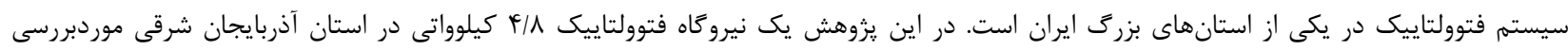

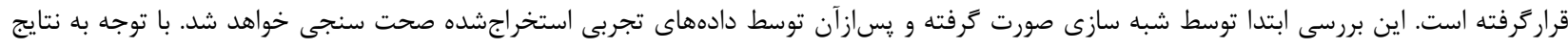

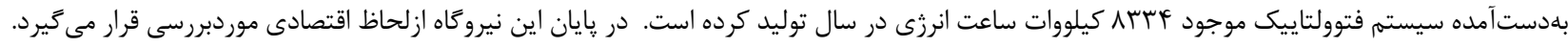

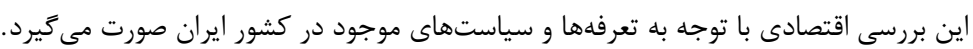

